\title{
The composition of rabbit's milk
}

\author{
By M. E. COATES, MARGARET E. GREGORY AND S. Y. THOMPSON \\ National Institute for Research in Dairying, Shinfield, Reading
}

(Received 28 May 1964-Accepted 23 Fune 1964)

As part of a project on hand-rearing baby rabbits, it was necessary to know the composition of rabbit's milk so that a suitable milk-substitute diet could be prepared. The gross chemical composition of rabbit's milk has been studied in some detail by Folin, Denis \& Minot (1919), Bergman \& Turner (1937) and Neumeister \& Krause (1956), but little is known about its vitamin content. We have therefore analysed samples of milk taken from New Zealand White and Chinchilla rabbits at different stages in the lactation cycle and report here their chemical composition and vitamin content.

\section{EXPERIMENTAL}

\section{Milk samples}

Samples of milk were obtained from one Chinchilla and seven New Zealand White rabbits. Litters were removed from the lactating does on the evening before the sample was taken. The following morning each doe was given 2.5 i.u. oxytocin by injection into the ear vein and milk was expressed by gently massaging the mammary tissue. Milk flow usually began about $3 \mathrm{~min}$ after the injection and continued for about $15 \mathrm{~min}$. Up to the 2oth day of lactation volumes of $10-35 \mathrm{ml}$ per doe were obtained, the average being about $20 \mathrm{ml}$; only very small quantities of milk could be expressed from does in later stages of lactation. Samples of colostrum were taken within $24 \mathrm{~h}$ of the birth of the litter.

For full chemical and vitamin analysis of some of the samples, the milks from two rabbits at similar stages of lactation were bulked. In this way two mixed samples representing the ist and 3 rd weeks of lactation were obtained. Other samples were analysed individually.

A portion of each sample (usually $5 \mathrm{ml}$ ) was set aside for chemical analysis. The remainder was weighed and centrifuged and the cream layer was removed, weighed and used for the measurement of vitamin A. The fat content of the cream, and thus of the whole milk, was determined. The water-soluble vitamins were measured microbiologically in the skim milk, but the results were recalculated in terms of whole milk.

\section{Analytical methods}

Methods used for chemical measurement of major constituents and for the assay of vitamin $A$, biotin, nicotinic acid, pantothenic acid, riboflavine, vitamin $B_{6}$ and vitamin $B_{12}$ were those described by Gregory, Kon, Rowland \& Thompson (1955). 
Thiamine was measured microbiologically with Lactobacillus fermenti as described by Bánhidi (1958) and folic acid with Lactobacillus casei as described by Herbert (1961). Sodium and potassium were measured in protein-free filtrates with a Unicam SP 900 flame photometer.

\section{RESULTS AND DISCUSSION}

The chemical composition of the samples taken at different stages during the first 3 weeks of lactation is shown in Table 1 . All the samples had a high total solids content, the major part consisting of about equal quantities of protein and fat, with lactose present as a minor component. The levels of protein and fat were about four times those in cow's milk, whereas lactose was present at only about one-quarter of its concentration in cow's milk. It has been shown that the lactose content of cow's milk varies inversely with the sodium content (see Rook \& Wood, 1958). Since lactose and sodium are two of the main constituents concerned in maintaining the constancy of the osmotic properties of milk it is not surprising that the low level of lactose in rabbit's milk was compensated for by a sodium content higher than in cow's milk. 'The potassium content was similar to that in cow's milk (Rook, $196 \mathrm{r}$ ).

\section{Table I. Chemical composition of rabbit's milk at different stages of lactation}

\begin{tabular}{|c|c|c|c|c|c|c|}
\hline Constituent & $\begin{array}{l}\text { Colostrum } \\
\text { (I NZW) }\end{array}$ & $\begin{array}{l}4^{\text {th }} \text { day } \\
\text { (I NZW) }\end{array}$ & $\begin{array}{l}\text { Ist week } \\
\text { (2 NZW) }\end{array}$ & $\begin{array}{l}\text { 18th day } \\
\text { (1 NZW) }\end{array}$ & $\begin{array}{l}\text { 18th day } \\
\text { (I C) }\end{array}$ & $\begin{array}{l}3 \text { rd week } \\
(2 \mathrm{NZW})\end{array}$ \\
\hline olids $(\mathrm{g} / \mathrm{1} 00 \mathrm{~g})$ & $32 \cdot 6$ & $32 \cdot 1$ & 310 & $36 \cdot 0$ & $3 x \cdot 8$ & 257 \\
\hline $100 \mathrm{~g})$ & $17 \cdot 7$ & 10.2 & 14.3 & $15 \cdot 2$ & $16 \cdot 7$ & $22 \cdot 3$ \\
\hline $\begin{array}{l}\text { (anhydrous) } \\
\text { g) }\end{array}$ & $I \cdot 32$ & $1 \cdot 76$ & $I \cdot 29$ & $I \cdot 28$ & I.55 & $I \cdot 12$ \\
\hline $\begin{array}{l}\left.\text { (total } N \times 6.3^{8}\right) \\
g)\end{array}$ & - & - & $13 \cdot 2$ & - & 一 & $11 \cdot 9$ \\
\hline $\begin{array}{l}(\mathrm{mg} / 100 \mathrm{~g}) \\
(\mathrm{mg} / 100 \mathrm{~g})\end{array}$ & $\begin{array}{l}186 \\
123\end{array}$ & $\begin{array}{r}212 \\
82\end{array}$ & - & $\begin{array}{l}145 \\
160\end{array}$ & $\begin{array}{l}167 \\
140\end{array}$ & - \\
\hline
\end{tabular}

Numbers of animals are given in parentheses. NZW, New Zealand White; C, Chinchilla.

Our results for the major constituents of rabbit's milk are in agreement with those reported previously by Folin et al. (1919), by Bergman \& Turner (1937) and by Davies, Widdowson \& McCance (1964), but the total solids, fat and protein contents were lower than those reported by Neumeister \& Krause (1956). No significant changes during lactation could be established.

The vitamin content of the milk samples is shown in Table 2. Some significant changes during the lactation were noted. The contents of biotin, folic acid, nicotinic acid, thiamine and vitamin $\mathrm{B}_{6}$ were all lower in the colostrum sample than in the milk from the $4^{\text {th }}$ day onwards. Although similar changes in the levels of biotin and vitamin $B_{6}$ have been noted with cow's milk (Gregory, Ford \& Kon, 1958), the contents of nicotinic acid (Gregory et al. 1958), folic acid (Collins, Boldt, Elvehjem \& Hart, 1953) and thiamine (Houston, Kon \& Thompson, 1940) are greater in the colostrum than in the mature milk of the cow. On the other hand, the trends for vitamin $A$ and vitamin $B_{12}$ with high levels in the colostrum and the gradually decreasing levels as the lactation proceeds are similar to the trends of these vitamins in cow's milk (Henry, 
Houston \& Kon, 1940; Gregory et al. 1958). Levels of pantothenic acid and riboflavine were variable and showed no clear lactational trends. The one sample from a Chinchilla rabbit showed no marked difference in composition from those from the New Zealand White breed.

\section{Table 2. Vitamin content $(\mu \mathrm{g} / \mathrm{ml})$ of rabbit's milk at} different stages of lactation

\begin{tabular}{lcccccc}
\multicolumn{1}{c}{ Vitamin } & $\begin{array}{c}\text { Colostrum } \\
\text { (1 NZW) }\end{array}$ & $\begin{array}{c}\text { 4th day } \\
\text { (1 NZW) }\end{array}$ & $\begin{array}{c}\text { 1st week } \\
(2 \mathrm{NZW})\end{array}$ & $\begin{array}{c}\text { 18th day } \\
\text { (1 NZW) }\end{array}$ & $\begin{array}{c}\text { 18th day } \\
\text { (1 C) }\end{array}$ & $\begin{array}{c}\text { 3rd week } \\
\text { (2 NZW) }\end{array}$ \\
Biotin & 0.08 & 0.17 & 0.23 & 0.45 & 0.30 & 0.14 \\
Folic acid & 0.003 & 0.013 & 0.10 & $c .0 .30$ & $c .0 .25$ & - \\
Nicotinic acid & 2.0 & 7.0 & 8.4 & 4.9 & 5.0 & 8.7 \\
Calcium pantothenate & 14.3 & 22.1 & 15.8 & 14.5 & 6.2 & 7.3 \\
Riboflavine & 2.9 & 2.3 & 2.3 & 4.6 & 4.9 & 2.8 \\
Thiamine & 0.3 & 0.6 & 1.7 & 1.6 & 1.0 & 1.7 \\
Vitamin B (as pyridoxal) & 0.9 & 2.1 & 2.9 & 3.6 & 3.2 & 2.5 \\
Vitamin B & 0.11 & 0.11 & 0.09 & 0.07 & 0.06 & 0.05 \\
Vitamin A & 6.70 & 3.05 & 2.71 & 1.82 & 2.34 & 0.84
\end{tabular}

Numbers of animals are given in parentheses. NZW, New Zealand White; C, Chinchilla.

The mature rabbit milk was richer than cow's milk in all the water-soluble vitamins and vitamin $\mathrm{A}$. We have been unable to find any published work on the vitamin content of rabbit's milk, other than that of Nixon (1953) who measured its inositol content.

\section{SUMMARY}

I. The chemical composition and vitamin content of samples of rabbit's milk obtained at different stages during the lactation cycle have been measured.

2. The samples all had high total solids contents, consisting of $10 \cdot 2-17 \cdot 7 \%$ fat, II $\cdot 9-13 \cdot 2 \%$ protein and $1 \cdot 12-1 \cdot 76 \%$ lactose. The potassium and sodium concentrations ranged from 145 to 212 and from 82 to $160 \mathrm{mg} / \mathrm{r} 00 \mathrm{~g}$ respectively. No marked changes in gross chemical composition during lactation could be established.

3. The milk was rich in all the water-soluble vitamins and vitamin A. Some effects of stage of lactation were noted. The levels of biotin, folic acid, nicotinic acid and vitamin $B_{6}$ were all lower, whereas those of vitamin $B_{12}$ and vitamin $A$ were higher in colostrum than in the milk. Levels of pantothenic acid and riboflavine were variable and no lactational trends could be established.

We are indebted to $\mathrm{Mr} \mathrm{A}$. Wagstaff for the chemical analyses of the milk samples and to Mr E. V. Ruby for care of the rabbits.

\section{REFERENCES}

Bánhidi, Z. G. (1958). Acta chem. scand. 12, 517.

Bergman, A. J. \& Turner, C. W. (1937). F. biol. Chem. I20, 21.

Collins, R. A., Boldt, R. E., Elvehjem, C. A. \& Hart, E. B. (1953). F. Dairy Sci. 36, 24.

Davies, J. S., Widdowson, E. M. \& McCance, R. A. (1964). Brit. F. Nutr. 18, 385. 
586 M. E. Coates, Margaret E. Gregory and S. Y. Thompson I964

Folin, O., Denis, W. \& Minot, A. S. (1919). F. biol. Chem. 37, 349.

Gregory, M. E., Ford, J. E. \& Kon, S. K. (1958). I. Dairy Res. 25, 447.

Gregory, M. E., Kon, S. K., Rowland, S. J. \& Thompson, S. Y. (1955). F. Dairy Res. 22, 108.

Henry, K. M., Houston, J. \& Kon, S. K. (1940). Ұ. Dairy Res, II, I.

Herbert, V. (1961). Y. clin. Invest. 40, 81.

Houston, J., Kon, S. K. \& Thompson, S. Y. (1940). J. Dairy Res. I1, 45.

Neumeister, H. \& Krause, B. (1956). Arch. Gefluggelz. Kleintierk. 5, 199.

Nixon, D. A. (1953). F. Physiol. 120, 27 P.

Rook, J. A. F. (1961). Dairy Sci. Abstr. 23, $25 \mathrm{I}$.

Rook, J. A. F. \& Wood, M. (1958). Nature, Lond., r81, 284. 